\title{
PREVALENCE AND FACTORS ASSOCIATED WITH PERIPHERAL AND CENTRAL ADIPOSITY IN PRIMARY SCHOOL STUDENTS IN BRAZIL
}

\author{
Alberto De Vitta ${ }^{1}$, Diego Silvestre de Barros², Roger Palma ${ }^{3}$, Marcus Vinícius Flores Soares ${ }^{4}$, \\ Marta Helena Souza De Conti ${ }^{5}$, Márcia Aparecida Nuevo Gatti ${ }^{6}$, \\ Sandra Fiorelli de Almeida Penteado Simeão?
}

\begin{abstract}
The objective was to identify the prevalence of excess central adiposity and peripheral schoolchildren and its relationship with sedentary activities and physical activity level. Cross-sectional study was conducted with 524 elementary school student's city of Bauru (SP). Structured protocol was used, the PAQ-C and measured subscapular skinfolds thickness (PCS) and triciptal (TSF). There were descriptive analyses, bivariate and multivariate logistic regression. The PCT and PCS rates were respectively $13.6 \%$ and $16.5 \%$ in boys and $15.4 \%$ and $12.6 \%$. In girls the frequency above three times a week on the computer and its use for more than three hours if associated with elevated PCT, low level of physical activity was associated with elevated PCS in boys, low level of physical activity and use of computer and / or video games for more than three hours/day were associated with higher PCS in boys. The frequency and number of hours in sedentary and low physical activity are important predictors of adiposity among children.
\end{abstract}

Key words: skinfold thickness, adolescent, risk factors, prevalence, anthropometry.

\section{INTRODUCTION}

In the last century the urbanization process that occurred in many countries brought changes to people's lifestyle, encouraging inadequate dietary habits, which has resulted in overweight and obesity increase on different population strata ${ }^{1}$.

In the USA, generally between $20 \%$ and $27 \%$ of children and adolescents are affected by obesity². In the city of Santos (São Paulo State, Brazil) the prevalence of overweight and obesity is respectively $15.7 \%$ and $18 \%$ among young people ${ }^{3}$. In another study with 1,057 children from 7 to 10 years old, prevalence was $7.0 \%$ for overweight and $3.0 \%$ for obesity ${ }^{4}$.

Diverse methods are described in literature to identify obesity, such as hydrometry, plethysmography, bioelectrical impedance, Body
Mass Index (IMC), arms, waist and hip circumferences, subscapular skinfolds thickness (SST) and tricipital skinfolds thickness (TST), among others. Measurements of TST and SST have long been used to estimate central and peripheral adiposity on field and clinical situations due to its ease of use, high accuracy and relatively low cost (compared to other techniques) ${ }^{5}$.

The etiology for increased central and peripheral adiposity is multifactorial and involves behavioral aspects (low physical activity level, excessive hours of sedentary activities and high caloric intake), as well as genetic and socioeconomic conditions ${ }^{6}$. For public municipal schools of Campo Grande (Mato Grosso do Sul State), there was excessive central and peripheral adiposity, although no association was found with sedentary activities ${ }^{7}$. In Pelotas (Rio Grande do Sul State), the prevalence

\footnotetext{
Professor of Physiotherapy and Masters in Public Health from the Universidade do Sagrado Coração (USC).

Masters student in Public Health from the Universidade do Sagrado Coração (USC).

3 Masters student in Public Health from the Universidade do Sagrado Coração (USC).

4 Masters student in Public Health from the Universidade do Sagrado Coração (USC).

5 Professor of Physiotherapy and Masters in Public Health from the Universidade do Sagrado Coração (USC).

6 Professor of Masters in Public Health from the Universidade do Sagrado Coração (USC).

7 Professor of Masters in Public Health from the Universidade do Sagrado Coração (USC). Corresponding Author: albvitta@yahoo.com.br
}

Suggested citation: De Vitta A, et al. Prevalence and factors associated with peripheral and central adiposity in primary school students in Brazil. Journal of Human Growth and Development 2013; 23(3): 365-371

Manuscript submitted Feb 13 2012, accepted for publication Jul 202013. 
of high SST and TST were present for both genders, associated to the mother's body mass index and to low level of physical activity on girls, and to schooling and economic level on boys ${ }^{8}$.

This study is justified by presenting data on the prevalence of adiposity of adolescents from the city of Bauru and on the variables that influence overweight. These data are important support for Education and Health managers of the city, so that they can plan nutrition policies and effective policies on healthy life habits.

The objective was to identify the prevalence of excessive central and peripheral adiposity of adolescents and its relationship with sedentary activities (TV, computer and/or videogame hours) and physical activity levels.

\section{Materials and methods}

This is a cross-sectional study in the 2009 school year, on the students (between the ages of 10 and 14 ) population enrolled in the $5^{\text {th }}$ and $8^{\text {th }}$ grades from all five public municipal elementary schools of Bauru.

The sampling process took place through a multistage technique: first, the stratified sampling was proportional to the number of students of each school, followed by random sampling within each school, including all urban public municipal schools. This sampling process allowed equal probability for each school to be selected.

The sample size to assess the prevalence of high body adiposity was calculated from the population of 1,505 students enrolled in primary schools of five public municipal schools of Bauru. For this analysis we have adopted: prevalence of $50 \%$ (prevalence unknown), acceptable error of four percentage points, confidence level of $95 \%$, design effect of 1.5 and the addition of $15 \%$ for possible losses and refusals. Considering these points, we estimated a total of 524 students.

The adopted criteria for exclusion of any randomly selected student for the study were: (a) aged under 10 and over 15; (b) not submitting the written informed consent form (WICF) signed by their parents; (c) some physical problem that temporarily or definitively prevented them of undergoing anthropometric measurements. Those who refused to participate in the study were deemed refusal.

\section{Proceedings}

The city Department of Education issued an authorization letter in which parents of students were informed about ethical aspects and signed a consent form. The project was approved by the Ethics Committee of the Sagrado Coração University.

The collection took place from February to May 2009, with the collaboration of the teachers from each class, who sent a student at a time to answer the interview. We explained the study objectives to each student and the researcher performed the structured interview, question by question. After answering the questions, the student was subjected to anthropometric measurements. Each individual approach took approximately thirty minutes.

The responsible team for data collection was composed of a Physical Educator, Graduated student of the Oral Biology Program, a Public Health concentration area in the Sagrado Coração University (USC). The graduate student was trained on a standard protocol for data collection (theoretical and practical), which was previously established in order to minimize possible inter- and intra-evaluation errors. The technical assessment error in the collection team was not determined, but $10 \%$ of the students sample was doubleassessed for quality control of anthropometrical measurements.

The variables (age, gender, school grade and sedentary activities - TV, computer and/or videogame hours), were collected through the questionnaire ${ }^{9}$, which consisted of the following questions: age $(10,11,12,13$ and 14 years old); gender; "In a normal school week, do you watch the TV?" (yes/no); "In a normal school week, how many times do you watch the TV?" (once, twice, three times, four times, five times or more a week); "In a normal school week, for how many hours do you watch the TV?" (less than an hour, two hours, three hours, four hours, five hours or more a day); "In a normal school week, how many times do you play the videogame at home?" (once, twice, three times, four times, five times or more a week); "In a normal school week, for how many hours do you use computer or play the videogame?" (less than an hour, two hours, three hours, four hours, five hours or more a day).

The regular physical activity level was assessed through the physical activity questionnaire for older children (PAQ-C) ${ }^{10}$ which was translated and modified in Brazil ${ }^{11}$. It consists of nine questions regarding sports and games practice, physical activities at school and in leisure time, including weekends. Each item of the questionnaire is given an answer from 1 to 5 , and the final score is obtained by the mean of the answers, representing the range from very sedentary (1) to very active (5). The scores 2, 3 and 4 respectively indicate the categories sedentary, moderately active and active. Thus, individuals can be classified into active or sedentary, based on the score. Active individuals are those who show a 33 score, whilst sedentary individuals show a $<3$ score.

For question number 1 , which comprises a list of activities, it was necessary to transform this score scale, by dividing the total points by the number of activities on the list, including also activities that had been added to the section "others".

The same type of procedure was necessary to question number 13 , which indicates the physical activity level for each day of the week. The total points of this question was divided by 7 . The final 
score is obtained by the score means of questions 1 to 7,9 and 13 .

The variables set (age, gender and practice of competition sports, sedentary activities - TV, computer and/or videogame hours, and physical activity level) was considered to be independent.

The subscapular skinfolds thickness (SST) and tricipital skinfolds thickness (TST), which we considered dependent variables, were measured with the Cescorf scientific adipometer, which is a Brazilian model, similar in design and mechanics to the English Harpenden caliper, with assumed constant pressure for any opening of the jaws around $10 \mathrm{~g} / \mathrm{mm}^{2}$, measuring the $0.1 \mathrm{~mm}$ unit, and contact area (surface) of $90 \mathrm{~mm}^{2}$. Measurements were taken according to the recommendations of Guedes \& Guedes ${ }^{12}$. Skinfolds measurements were taken three times each, not consecutively, and the mean values were used for analysis.

Central and peripheral adiposity were classified as high when values corresponded to $90 \%$ of the reference distribution per age and gender, according to the curve of the Center for Disease Control and Prevention (CDC) ${ }^{13}$. Values lower than $90 \%$ were considered normal adiposity.

\section{Results analysis}

Data were inserted in a database and analyses were stratified by gender, using SPSS ( $\mathrm{v}$.
10.0) statistics software. The analysis was carried through descriptive and analytical approaches. On the descriptive approach, distributions of absolute and relative frequencies were made for categorical variables; mean and standard deviation were used for continuous variables. On the analytical approach a bivariate analysis was carried on through Pearson test, and a multivariate analysis through binary logistic regression was used, following the hierarchical model to determine body adiposity, hypothetically temporal ${ }^{14}$. The method of introducing variables in the adopted models was "backward stepwise". We considered a significance level of $5 \%$ and confidence interval (CI) of $95 \%$, with calculation of adjusted "odds ratios"15.

\section{Results}

The sample was evenly distributed by gender, i.e. 278 boys (53.1\%) and 246 girls (46.9\%). The equality of numbers for boys and girls occurred coincidentally after closing the database. The study excluded $2.3 \%$ of adolescents for not being within the appropriate age range for the considered school grades.

In Table 1, there was higher prevalence of sedentary students of both genders, and high TST and SST frequencies were respectively $13.4 \%$ and $16.5 \%$ for boys and $15.5 \%$ and $12.7 \%$ for girls.

Table 1: Distribution of absolute and relative frequencies of sedentary activities, physical activity level, triceps and subscapular skinfold, by gender. (Students of Bauru)

\begin{tabular}{|c|c|c|c|c|}
\hline Factor & $\begin{array}{l}\text { Response } \\
\text { Sedentary }\end{array}$ & $\begin{array}{l}M(\mathbf{n}=\mathbf{2 7 8}) \\
154(55.4 \%)\end{array}$ & $\begin{array}{l}\mathbf{F}(\mathbf{n}=\mathbf{2 4 6}) \\
200(81.3 \%)\end{array}$ & $\begin{array}{c}\text { Total } \\
\mathbf{N}=\mathbf{5 2 4} \\
354(67.5 \%)\end{array}$ \\
\hline & Active & $124(44.6 \%)$ & $46(18.7 \%)$ & $170(23.5 \%)$ \\
\hline Tricipital Skinfold & $\begin{array}{l}<\text { P90 } \\
>\text { P90 }\end{array}$ & $\begin{array}{c}240(83.3 \%) \\
38(13.6 \%)\end{array}$ & $\begin{array}{c}208(84.5 \%) \\
38(15.5 \%)\end{array}$ & $\begin{array}{c}448(85.4 \%) \\
76(14.6 \%)\end{array}$ \\
\hline Subscapular Skinfold & $<$ P90 & $232(83.4 \%)$ & $215(87.3 \%)$ & $447(85.3 \%)$ \\
\hline TV frequency & Less than twice & $\begin{array}{l}46(16.6 \%) \\
48(17.9 \%)\end{array}$ & $\begin{array}{l}31(12.7 \%) \\
38(15.8 \%)\end{array}$ & $\begin{array}{l}77(14.7 \%) \\
85(16.7 \%)\end{array}$ \\
\hline & Less than 2 hours & $78(29.2 \%)$ & $\begin{array}{c}202(84.2 \%) \\
71(29.5 \%)\end{array}$ & $\begin{array}{l}421(83.3 \%) \\
148(29.2 \%)\end{array}$ \\
\hline TV hours per day & Three hours or more & $189(70.8 \%)$ & $169(70.5 \%)$ & $358(70.8 \%)$ \\
\hline Computer Frequency & $\begin{array}{l}\text { Less than twice } \\
\text { Three times or more }\end{array}$ & $\begin{array}{l}102(45.5 \%) \\
122(54.5 \%)\end{array}$ & $\begin{array}{c}81(40.0 \%) \\
121(60.0 \%)\end{array}$ & $\begin{array}{l}183(42.9 \%) \\
243(57.1 \%)\end{array}$ \\
\hline Computer hours per day & $\begin{array}{l}\text { Less than } 2 \text { hours } \\
\text { Three hours or more }\end{array}$ & $\begin{array}{c}94(41.9 \%) \\
130(58.1 \%)\end{array}$ & $\begin{array}{c}90(44.5 \%) \\
112(55.5 \%)\end{array}$ & $\begin{array}{l}184(43.1 \%) \\
242(56.9 \%)\end{array}$ \\
\hline
\end{tabular}

In bivariate analysis (Table 2), we found that skinfold thickness was associated with com- puter hours and frequency and with sedentary lifestyle.

Table 2: Distribution of absolute and relative frequencies of skinfold thickness of male students and values of the statistics test. (Students of Bauru)

\begin{tabular}{|c|c|c|c|c|c|}
\hline \multirow{2}{*}{ Factor } & \multirow{2}{*}{ Response } & \multicolumn{2}{|c|}{ High Tricipital } & \multicolumn{2}{|c|}{ High Subscapular } \\
\hline & & n (\%) & p value & n (\%) & p value \\
\hline TV Frequency & $\begin{array}{l}\text { Less than twice } \\
\text { Three times or more }\end{array}$ & $\begin{array}{c}7(18.4) \\
31(81.6)\end{array}$ & $p>0.05$ & $\begin{array}{c}7(15.5) \\
38(84.5)\end{array}$ & $p>0.05$ \\
\hline TV Hours & $\begin{array}{l}\text { Less than } 2 \text { hours } \\
\text { Three hours or more }\end{array}$ & $\begin{array}{c}5(12.1) \\
36(87.9)\end{array}$ & $p<0.05$ & $\begin{array}{c}6(12.7) \\
41(87.3)\end{array}$ & $p<0.05$ \\
\hline Computer Frequency & $\begin{array}{l}\text { Less than twice } \\
\text { Three times or more }\end{array}$ & $\begin{array}{l}17(45.9) \\
20(54.1)\end{array}$ & $p<0.05$ & $20(50.0)$ & $p>0.05$ \\
\hline Computer Hours & $\begin{array}{l}\text { Less than } 2 \text { hours } \\
\text { Three hours or more }\end{array}$ & $\begin{array}{c}6(16.2) \\
31(83.8)\end{array}$ & $p<0.05$ & $\begin{array}{l}10(23.2) \\
33(76.8)\end{array}$ & $p<0.05$ \\
\hline PAQ & $\begin{array}{l}\text { Sedentary } \\
\text { Active }\end{array}$ & $\begin{array}{l}26(68.4) \\
12(31.6)\end{array}$ & $p<0.05$ & $\begin{array}{l}33(71.7) \\
13(28.3)\end{array}$ & $p<0.05$ \\
\hline
\end{tabular}


In table 3, the low level of physical activity showed association with the TST.

In Table 4, both skinfold thickness types were associated with TV hours and computer hours, whilst computer frequency was only associated with tricipital skinfold.

In girls the frequency above three times a week on the computer and your for more than three hours if associated with TST high (table 5).

\section{DISCUSSION}

In this study high frequencies of subscapular skinfolds thickness and triciptal were respectively $13.4 \%$ and $16.5 \%$ for boys and $15.5 \%$ and $12.7 \%$ for girls. In Southern Brazil, the percentage of high TST on boys was $20.2 \%$, and high SST was $17.3 \%$; the high percentage of skinfold thickness on girls was $14.2 \%$ for TST and $10.5 \%$ for SST ${ }^{8}$. In

Table 3: Analysis of logistic regression among skinfold thickness and independent variables of male students. (Students of Bauru)

\begin{tabular}{|c|c|c|c|c|c|}
\hline \multirow{2}{*}{ Factor } & \multirow{2}{*}{ Response } & \multicolumn{2}{|c|}{ High Tricipital } & \multicolumn{2}{|c|}{ High Subscapular } \\
\hline & & n (\%) & p value & n (\%) & p value \\
\hline TV Frequence & $\begin{array}{l}\text { Less than twice } \\
\text { Three times or more }\end{array}$ & $\begin{array}{c}1,0 \\
0,9(0,7-1,2)\end{array}$ & 0,69 & $\begin{array}{c}1,0 \\
0,9(0,9-1,0)\end{array}$ & 0,35 \\
\hline TV Hours & $\begin{array}{l}\text { Less than } 2 \text { hours } \\
\text { Three times or more }\end{array}$ & $\begin{array}{c}1,0 \\
1,0(0,9-1,3)\end{array}$ & 0,48 & $\begin{array}{c}1,0 \\
1,0(0,9-1,0)\end{array}$ & 0,30 \\
\hline Computer frequence & $\begin{array}{l}\text { Less than twice } \\
\text { Three times or more }\end{array}$ & $\begin{array}{c}1,0 \\
1,28(0,46-3,54)\end{array}$ & 0,62 & $\begin{array}{c}1,0 \\
1,0(0,7-1,3)\end{array}$ & 0,95 \\
\hline Computer Hours & $\begin{array}{l}\text { Less than } 2 \text { hours } \\
\text { Three times or more }\end{array}$ & $\begin{array}{c}1,0 \\
1,1(0,90-1,50)\end{array}$ & 0,19 & $\begin{array}{c}1,0 \\
0,99(0,99-1,00)\end{array}$ & 0,09 \\
\hline PAQ & $\begin{array}{l}\text { Sedentary } \\
\text { Active }\end{array}$ & $\begin{array}{c}1,0 \\
1,92(0,52-3,93)\end{array}$ & 0,05 & $\begin{array}{c}1,0 \\
2,38(1,17-4,76)\end{array}$ & 0,01 \\
\hline
\end{tabular}

Tabela 4: Distribution of absolute and relative frequencies of skinfold thickness of female students and values of the statistics test. (Students of Bauru)

\begin{tabular}{|c|c|c|c|c|c|}
\hline \multirow{2}{*}{ Factor } & \multirow{2}{*}{ Response } & \multicolumn{2}{|c|}{ High Tricipital } & \multicolumn{2}{|c|}{ High Subscapular } \\
\hline & & n (\%) & p value & n (\%) & p value \\
\hline TV Frequence & $\begin{array}{l}\text { Less than twice } \\
\text { Three times or more }\end{array}$ & $\begin{array}{c}5(13,1) \\
33(86,9)\end{array}$ & $p>0,05$ & $\begin{array}{c}6(20,0) \\
24(80,0)\end{array}$ & $p>0,05$ \\
\hline TV Hours & $\begin{array}{l}\text { Less than } 2 \text { hours } \\
\text { Three times or more }\end{array}$ & $\begin{array}{l}7(18,4) \\
31(81,6)\end{array}$ & $p<0,05$ & $\begin{array}{c}6(20,0) \\
24(80,0)\end{array}$ & $p<0,05$ \\
\hline Computer frequence & $\begin{array}{l}\text { Less than twice } \\
\text { Three times or more }\end{array}$ & $\begin{array}{c}7(35,0) \\
13(65,0)\end{array}$ & $p<0,05$ & $\begin{array}{l}12(54,5) \\
10(45,4)\end{array}$ & $p>0,05$ \\
\hline Computer Hours & $\begin{array}{l}\text { Less than } 2 \text { hours } \\
\text { Three times or more }\end{array}$ & $\begin{array}{c}9(25,7) \\
26(74,3)\end{array}$ & $p<0,05$ & $\begin{array}{c}6(20,0) \\
24(80.0)\end{array}$ & $p<0,05$ \\
\hline PAQ & $\begin{array}{c}\text { Sedentary } \\
\text { Active }\end{array}$ & $\begin{array}{l}26(78,1) \\
7(21,2)\end{array}$ & $p>0,05$ & $\begin{array}{l}23(74,2) \\
8(25,8)\end{array}$ & $p>0,05$ \\
\hline
\end{tabular}

Table 5: Analysis of logistic regression among skinfold thickness and independent variables of female students. (Students of Bauru)

\begin{tabular}{|c|c|c|c|c|c|}
\hline \multirow{2}{*}{ Factor } & \multirow{2}{*}{ Response } & \multicolumn{2}{|c|}{ High Tricipital } & \multicolumn{2}{|c|}{ High Subscapular } \\
\hline & & n (\%) & p value & n (\%) & p value \\
\hline TV Frequence & $\begin{array}{l}\text { Less than twice } \\
\text { Three times or more }\end{array}$ & $\begin{array}{c}1,0 \\
1,0(0,7-1,4)\end{array}$ & 0,79 & $\begin{array}{c}1,0 \\
0,8(0,6-1,2)\end{array}$ & 0,43 \\
\hline TV Hours & $\begin{array}{l}\text { Less than } 2 \text { hours } \\
\text { Three times or more }\end{array}$ & $\begin{array}{c}1,0 \\
0,9(0,9-1,3)\end{array}$ & 0,79 & $\begin{array}{c}1,0 \\
1,0(0,6-1,4)\end{array}$ & 0,18 \\
\hline Computer frequence & $\begin{array}{l}\text { Less than twice } \\
\text { Three times or more }\end{array}$ & $\begin{array}{c}1,0 \\
1,001(1,000-1,002)\end{array}$ & 0,02 & $\begin{array}{c}1,0 \\
1,001(1,000-1,002)\end{array}$ & 0,08 \\
\hline Computer Hours & $\begin{array}{l}\text { Less than } 2 \text { hours } \\
\text { Three times or more }\end{array}$ & $\begin{array}{c}1,0 \\
2,82(1,10-7,22)\end{array}$ & 0,03 & $\begin{array}{c}1,0 \\
1,99(0,88-4,48)\end{array}$ & 0,09 \\
\hline PAQ & $\begin{array}{l}\text { Sedentary } \\
\text { Active }\end{array}$ & $\begin{array}{c}1,0 \\
0,92(0,37-2,26)\end{array}$ & 0,86 & $\begin{array}{c}1,0 \\
1,24(0,52-2,95)\end{array}$ & 0,62 \\
\hline
\end{tabular}

Florianópolis (Santa Catarina State), we noticed that the percentage of high skinfold thickness was $8.7 \%$ for TST and $10.3 \%$ for SST on boys, and $6.3 \%$ for TST and $11.1 \%$ for SST on girls ${ }^{16}$.

We also noticed that for both genders there was higher prevalence of sedentary students. Other studies in Brazil pointed out that physical inactivity reaches a percentage of around $50 \%$ to $60 \%{ }^{17}$. A systematic review showed that the prevalence of
Brazilian adolescents exposed to low levels of physical activity varied from $39 \%$ to $93.5 \%{ }^{18}$ - in Rio de Janeiro, approximately $85 \%$ of male adolescents and $94 \%$ female adolescents were classified as sedentary ${ }^{11}$.

It should be noted in this study that there was Association the low level of physical activity with the PCS in boys. In Pelotas, Brazil, has been identified for significant difference between low level 
of physical activity and the subscapular skin fold in schoolchildren female ${ }^{8}$

In Turkey, sedentary students were 1.55 times more likely to have increased adiposity when compared to active students ${ }^{19}$. In Mexico, the practice of physical activities was identified as a protective factor (0.78: 067-091 ${ }^{19}$. In schools of Florianópolis (Santa Catarina State, Brazil), there was no association between physical inactivity and high skinfold thickness ${ }^{16}$.

Physical inactivity results in increased cost for the individual, their family and for society. According to the World Health Organization, the practice of regular physical activity prevents excess weight (reducing the risk of obesity), assists in the prevention of hypertension and osteoporosis, promotes well-being and reduces stress, anxiety and depression ${ }^{20}$. Longitudinal studies evidence that physical inactivity, when initiated in childhood and/ or adolescence tends to continue into adulthood, and it is more difficult to change, which results in increased emergence and development of morbidities throughout early ages, with great repercussion in adult age ${ }^{21,22}$.

Regarding the use of TV and computer/ videogame, we noticed that $96.6 \%$ of students watch TV, and $82.1 \%$ of those watch it three or more days a week and $70.8 \%$ do it for three or more hours a day. As for computer use, we noticed that $81.3 \%$ have the habit of using it and among those, $54.5 \%$ use it three or more times a week, and $58.1 \%$ for three or more hours a day.

In the city of Ilhabela (São Paulo State) the average TV hours for the total sample was $3.7 \pm$ 2.4 hours $(3.6 \pm 2.3$ hours for boys and $3.8 \pm 2.5$ hours for girls ${ }^{23}$ ). Similar values of 4.4 and 4.9 hours for boys and girls, respectively, were found in Niterói (Rio de Janeiro State) ${ }^{11}$.

The values found in this study and the values found in literature are above the recommendations of the American Academy of Pediatrics for children and adolescents, which are limited to a maximum of 2 hours a day to watch TV24.

In this study it was observed that, in girls, the frequency above three times during the week on the computer and its use by more than three horasdia if associated with the TST. For students from the city of João Pessoa (Paraíba State, Brazil), the chance of presenting excess weight was $81 \%$ (CI 95\% $=1.23$ 2.65) higher among boys who watched TV, when compared to the ones who performed other activities $^{25}$. In a city of the Southern Brazil there was found strong association between excess weight and sedentary habits ${ }^{26}$. This fact was not evidenced on students from Florianópolis, Santa Catarina, Brazil ${ }^{16}$.

In Switzerland, authors reported that among the risk/protective factors detected, the number of hours per day individuals used to play electronic games $(O R=2.03 ; 1.57-2.61)$ and the number of hours per day individuals watched TV $(O R=2.83$; 2.08-3.86) were associated with high scapular and tricipital skinfold thickness ${ }^{27}$. In other studies no significant association was observed between these variables ${ }^{28,29}$

The association between the habit of using electronic devices and the increase of obesity in children possibly happens due to the sedentary nature of the activity, plus the relationship between it and the intake of high sugar and fat foods, as well as the cumulative effect of exposition to hypercaloric food advertisement ${ }^{30}$.

Limited leisure areas (due to urbanization) and attractive home entertainment, such as television, computers and videogames, worsen the situation. For children, playing videogames is more interesting than performing physical activities that require physical exertion. The pleasure of electronic activity substituted the old habit of playing jump rope, hide and seek and other games that require energy expenditure ${ }^{30}$.

Despite emphasizing the importance of investigating behavioral factors linked to the increase of adiposity in adolescence, the interpretation should be made with caution, since this work is based on cross-sectional design and, therefore, the causality denotation should be interpreted carefully. Besides that, associations described between various factors and high skinfold thickness may have been mistaken by nonmeasured factors, such as dietary intake and race, creating limitations for this study.

However, control of confounding variables by regression analysis is an important feature. Moreover, the fact that the anthropometric data collection and behavioral characteristics were performed by only one researcher contributes to reduce biases of measures and responses. Also, the meeting of associations confirms literature findings and similar objectives and delineations.

Through studies like this, identification of population groups at risk and factors that influence harmful health habits in childhood and adolescence is fundamental for the development of intervention policies and programs aimed at controlling chronic diseases of adulthood. The results of this study suggest, as priority groups for intervention, the group of sedentary people and the individuals who use the computer or videogame with a frequency of three times or more per week, for more than three hours a day.

The results showed that schoolchildren showed frequencies of triciptal and subscapular skin folds that are compatible with the high literature; the girls above frequency three times a week on the computer and its use for more than for more than three hours a day is associated with the elevated PCT; that low level of physical activity was associated with the high PCS in boys. A relevant contribution is that data in this genre, and others who may elapse perfecting the understanding of relationships between variables and provide useful elements for the implementation of measures aimed at the maintenance, improvement and promotion of the physical well-being of schoolchildren. 


\section{REFERENCES}

1. Tardido AP, Falcão MC. O impacto da modernização na transição nutricional e obesidade. Rev Bras Nutr Clin 2006; 21(2): 117-124.

2. Santos LRC; Rabinovich EP. Situações Familliares na Obesidade Exógena Infantil do Filho Único. Rev Saúde Soc. 2011; 20(2):507-521.

3. Costa RF, Cintra IP, Fisberg M. Prevalência de sobrepeso e obesidade em escolares da cidade de Santos, SP. Arq Bras Endocrinol Metab 2006; 50:60-67.

4. Farias ES, Guerra-Junior G, Petroski EL. Estado nutricional de escolares em Porto Velho, Rondônia. Rev Nutr 2008; 21:401-409.

5. Souza ML, Sant'Anna S, Priore E, Carmo S, Franceschini C. Métodos de avaliação da composição corporal em crianças. Rev Paul Pediatr 2009; 27(3):315-321.

6. Enes CC, Slater B. Obesidade na adolescência e seus principais fatores determinantes. Rev. Bras. Epidemiol. 2010; 13(1): 63-171.

7. Piovesan AJ, Yonamine RS, Lopes AS, Correa Filho R. Adiposidade corpórea e tempo de assistência à tv em escolares de 11 a 14 anos de duas regiões geográficas do município de Campo Grande (MS). Rev Bras Cineantropom. Desempenho Hum. 2002; 4(1):17-24.

8. Duquia RP, Dumith SC, Reichert FF, Madriga SW, Duro LN, Menezes AMB, Araújo CL. Epidemilogia das pregas cutâneas tricipital e subescapular elevadas em adolescentes. Cad. Saúde Pública 2008; 24;113-121.

9. Harreby $M$, Nygaard $B$, Jessen $T$, Larsen $E$, Storr-Paulsen A, Lindahl A, Fisker I, Laegaard E. Risk factors for low back pain in a cohort of 1389 Danish school children: an epidemiologic study. Eur Spine J 1999; 8:444-450.

10. Crocker PR., Bailey DA, Faulkner RA, Kowalski KC, Mcgrath R. Measuring general levels of physical activity: Preliminary evidence for the Physical Activity Questionnaire for Older Children. Med Sci Sports Exerc 1997 29:13441349.

11. Silva RCR, Malina RM. Nível de atividade física em adolescentes do Município de Niterói, Rio de Janeiro, Brasil. Cad Saúde Pública 2000; 16(4):1091-1097.

12. Guedes DP, Guedes JERP. Manual prático para avaliação em educação física. Barueri, Manole, 2006.

13. Wells JC, Victora CG., Indices of whole-body and central adiposity for evaluating the metabolic load of obesity. Int J Obes (Lond) 2005; 29:483-489.

14. Victora CG, Huttly SR, Fuchs SC, Olinto MT. The role of conceptual frameworks in epidemiological analisys: a hierarchical approach. Int J Epidemiol 1997; 26:224-227.

15. Norman GR, Streiwner DL. (1994). Biostatitics: The base essentials, mosby-year book. St. Lowis, 260p.

16. Silva DAS, Pelegrini A, Silva JMFL, Petroski EL. Epidemiology of whole body, peripheral, and central adiposity in adolescents from a Brazilian state capital. Eur J Pediatr, 2011; DOI 10.1007/ s00431-011-1460-3.

17. Hallal PC, Bertoldi AD, Goncalves H, Victora CG. Prevalencia de sedentarismo e fatores associados em adolescentes de 10-12 anos de idade. Cad Saúde Publica 2006; 22(6): 1277-1287.

18. Tassitano RM, Bezerra J, Tenorio MCM, Colares V, Barros MVG, Hallal PC. Atividade fisica em adolescentes brasileiros: uma revisao sistematica. Rev Bras Cineantropom. Desempenho Hum. 2007; 9(1):55-60.

19. Salam H, Tar>m Ö. Prevalence and Correlates of Obesity in Schoolchildren from the City of Bursa, Turkey. J Clin Res Ped Endo 2008; 1(2):80-88.

20. Moraes AS, Rosas JB, Mondini L, Freitas ICM. Prevalência de sobrepeso e obesidade e fatores associados em escolares de área urbana de Chilpancingo, Guerrero, México, 2004. Cad. Saúde Pública, Rio, 2006; 22(6):1289-1301.

21. Oliveira TC, Silva AAM, Santos CJN, Silva JS, Conceição SIC. Atividade física e sedentarismo em escolares da rede pública e privada de ensino em São Luís. Rev Saúde Pública; 2010; 44(6): 996-1004.

22. Moraes ACF, Fernandes CAM, Elias RGME, Nakashima ATA, Reichert FF, Falcão MC'. Prevalência de inatividade física e fatores associados em adolescentes. Rev Assoc Med Bras 2009; 55(5): 523-528.

23. Guedes DP, Miranda Neto JT, Almeida MJ, Martins e Silva AJR. Impacto de fatores sociodemográficos e comportamentais na prevalência de sobrepeso e obesidade de escolares. Rev Bras Cineantropom Desempenho Hum 2010; 12(4):221-231.

24. Silva MDES, Teixeira PC, Matsudo S, Matsudo V. Relação do tempo de TV e aptidão física de escolares de uma região de baixo nível socioeconômico R. Bras. Ci e Mov. 2007; 15(4):21-30.

25. American Academy of Pediatrics. Smart Guide to Kid's TV Disponivel em: http://www.aap.org/ family/smarttv.htm.

26. Rech RR, Halpern $R$, Costanzi CB, Bergmann MLA, Alli LR, Mattos AP, Trentin L, Brum LR. Prevalência de obesidade em escolares de 7 a 12 anos de uma cidade Serrana do RS, Brasil. Rev Bras Cineantropom Desempenho Hum 2010, 12(2):90-97.

27. Novaes JF, Lamounier JA, Franceschini SCC, Priore SE. Fatores ambientais associados ao sobrepeso infantil. Rev. Nutr. 2009; 22(5): 661-673.

28. Stettler N, Signer TM, Suter PM. Electronic games and environment factors associated with childhood obesity in Switzerland. Obes Res 2004; 12:896-903.

29. Janssen I, Katzmarzyk PT, Boyce WF, Vereecken C, Mulvihill C, Roberts C, Currie C, Pickett W. Comparison of overweight and obesity prevalence in school-aged youth from 34 countries and their relationships with physical activity and dietary patterns. Obes Rev. 2005; 6(2):123-132.

30. Vandewater EA, Xuan Huang, MA. Parental Weight Status as a Moderator of the Relationship Between Television Viewing and Childhood Overweight. Arch Pediatr Adolesc Med. 2006; 160:425-431. 
